\title{
Riverine habitat specificity constrains dispersion in a Neotropical fish (Characidae) along Southern Brazilian drainages
}

\author{
Alice Hirschmann, Luiz R. Malabarba, Andréa Tonolli Thomaz \& Nelson J Rosa Fagundes
}

Submitted: 12 November 2014 Accepted: 23 January 2015

doi:10.1111/zsc.12106

\begin{abstract}
Hirschmann, A., Malabarba, L. R., Thomaz, A. T., Fagundes, N. J. R. (2015). Riverine habitat specificity constrains dispersion in a Neotropical fish (Characidae) along Southern Brazilian drainages. -Zoologica Scripta, 44, 374-382.

Freshwater fishes often display a marked phylogeographic structure strongly associated with historical and ecological changes in the aquatic environment. Different ecological conditions in the same river drainage may act as permeable barriers to dispersion and gene flow. Previous studies recognized two discrete spatial components for the ichthyofauna in the freshwater coastal drainages of southern Brazil: the lowland fish fauna in the lagoons and the fish fauna of the rivers flowing in the valleys. In order to test if the coastal lagoons may limit the dispersion of a riverine species, we describe the phylogeographic structure among populations of Cyanocharax itaimbe, a species endemic to this region. We analysed 55 specimens characterized for two mitochondrial and one nuclear genes. Sequences were analysed using gene trees and species tree approaches, together with standard population genetics methods. Molecular analyses indicated three evolutionary groups which diverged from each other between an estimated 1,600,000 and 450,000 years before the present. However, two currently isolated river systems share the same evolutionary clade, whereas a single drainage contains two different lineages. Our results indicate strong genetic structure among populations along with generally conserved morphology. The strong genetic structure among populations living in the same drainage system may be explained by ecological differences between lagoons and rivers (or palaeochannels) that act as barriers to dispersion.

Corresponding author: Alice Hirschmann, Programa de Pós-Graduação em Biologia Animal, Av. Bento Gonçalves, 9500, Universidade Federal do Rio Grande do Sul, 91501-970 Porto Alegre, Rio Grande do Sul, Brazil. E-mail: alicehirschmann@gmail.com

Luiz R. Malabarba, Departamento de Zoologia, Universidade Federal do Rio Grande do Sul, 91501-970 Porto Alegre, Rio Grande do Sul, Brazil. E-mail: malabarb@ufrgs.br

Andréa Tonolli Thomaz, Department of Ecology and Evolutionary Biology, Museum of Zoology, University of Michigan, 48109-1079 Ann Arbor, MI, USA. E-mail: thomaz@umich.edu

Nelson 7 Rosa Fagundes, Departamento de Genética, Universidade Federal do Rio Grande do Sul, 91501-970 Porto Alegre, Rio Grande do Sul, Brazil.E-mail: nelson.fagundes@ufrgs.br
\end{abstract}

\section{Introduction}

Freshwater fishes often display marked phylogeographic structure strongly connected to historical and ecological changes in the aquatic environment and landscapes (Bermingham \& Avise 1986; Bernatchez \& Wilson 1998; Rundle et al. 2000; Waters et al. 2007). In general, these organisms depend directly on connections between river basins for dispersion. Thus, a strong relationship is expected between the history of the basins and their associated ichthyofauna. In other words, for freshwater fishes, phylogeography is integrally linked to the landscape and to the landscape history (Avise 2000, 2009).

The landscape of the Brazilian Atlantic coastal region was formed by multiple geological processes since the breakup of the Gondwana ( 180 million years ago - Ma), including megadome uplift and erosion events (Ribeiro 2006). On a more recent timescale, climatic oscillations during the Pleistocene $(\sim 2.6 \mathrm{Ma})$ played a major role affecting this region due to the effects of sea level changes which impacted connections between rivers (Weitzman 
et al. 1988; Lundberg et al. 1998) and shifts in the extent of the Atlantic Rainforest cover (Carnaval \& Moritz 2008; Carnaval et al. 2009). In the latest $0.5 \mathrm{Myr}$, cycles of sea level changes were important for the present physiognomy of the Southern Coastal Plain. Sea level retreat resulted in the formation of several lagoons along the long coastal plain and interconnected previously isolated rivers draining from the Serra Geral highlands to the sea (Villwock 1984; Villwock \& Tomazelli 1995; Fig. 1). These rivers form a series of isolated hydrographic basins, collectively known as Coastal Drainages of Southeastern Brazil (CDSEB). Smaller isolated basins are separated from the large inland drainages by the scarped, mountainous landscapes of the eastern margin of the Brazilian mountain ranges that extend from southern to southeastern Brazil (Ribeiro 2006). Such historical isolation contributed to the evolution of a significant number of endemic species of fishes and other organisms (plants, mammals, frogs, etc.). This factor makes the CDSEB, and the presence of the Brazilian Atlantic Rainforest, one of the greatest hotspots of biodiversity in the world (Myers et al. 2000). For freshwater fishes, the endemism in relation to area is one of the highest in the Neotropical region (Vari 1988; Weitzman et al. 1988; Bizerril 1994; Buckup 2011).

A system of three small isolated drainages characterizes the southern portion of the CDSEB: the Rio Tramandaí, Rio Mampituba and Rio Araranguá, which comprise the Tramandaí-Mampituba Freshwater Ecoregion (unit 335 Abell et al. 2008; Fig. 1). This region is identified as an area of high endemism for species of fishes because of the congruent distributional patterns shared by several species solely found in these three drainages (Malabarba \& Isaia 1992; Reis \& Schaefer 1998). One of these river systems, the Rio Tramandaí, exhibits a distinctive feature: two rivers in this basin, the Rio Maquiné and Rio Três Forquilhas (Fig. 1) flow in isolation in different valleys of the Serra Geral, but are connected near their mouths by freshwater lagoons (Lagoa dos Quadros and Lagoa Itapeva) and small coastal plain channels. The other two rivers (Rio Mampituba and Rio Araranguá) run in complete isolation and then empty into the sea. These rivers are small and shallow with clear, cold waters, a rapid flow and rocky bottoms.

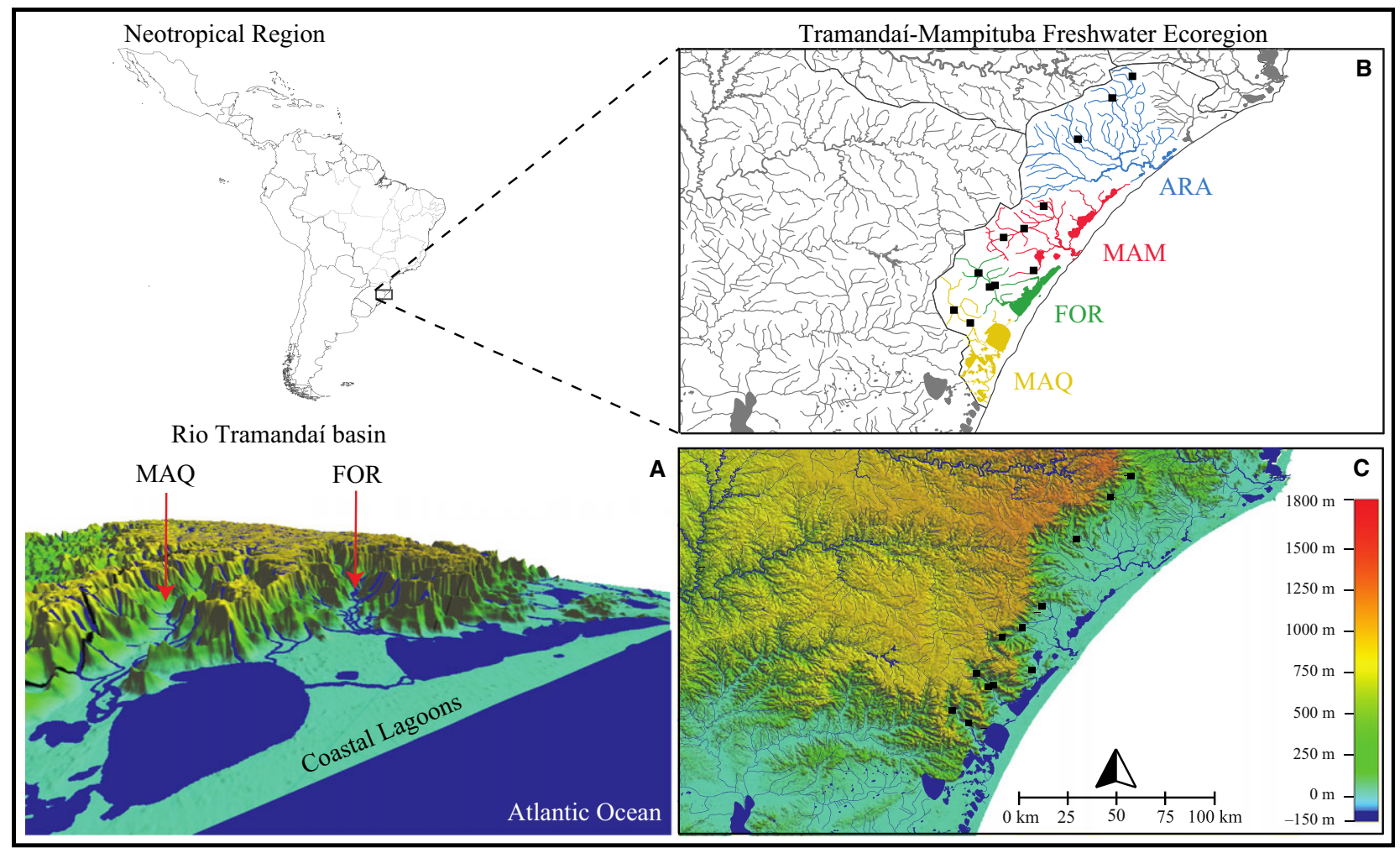

Fig. 1 Geographical distribution of Cyanocharax itaimbe. -A. 3D map highlighting of the Rio Tramandaí drainage demonstrating that the Rio Maquiné and Três Forquilhas are isolated upstream but connected downstream through freshwater lagoons and small channels in the coastal plain. The slope has been exaggerated for better visualization. - B. Tramandaí-Mampituba Freshwater Ecoregion, the region of focus in this study, is shown with different colours for each river basin/subbasin in the ecoregion; squares represent sampled localities of C. itaimbe. - C. Elevation map with sampling sites. 
Conversely, the freshwater lagoons connecting some of these rivers are large, circular/elliptical, shallow and sandy bottomed, with slow water flow. For example, both lagoons (Lagoa dos Quadros and Lagoa Itapeva) have a maximum depth of about $3.5 \mathrm{~m}$, whereas their surface areas are $119 \mathrm{~km}^{2}$ and $95.16 \mathrm{~km}^{2}$, respectively (Schwarzbold \& Schäfer, 1984). These characteristics result in higher turbidity and temperature in the lagoon than in the rivers.

The present configuration of the coastal plain and the formation of these freshwater lagoons are relatively young. According to Schwarzbold \& Schäfer (1984) the formation of Lagoa dos Quadros and Lagoa Itapeva dates to about 5 thousand years ago (ka). The Holocene transgression that covered the coastal plain with sandy barriers is no more than $5 \mathrm{ka}$ in age. The formation of these Holocene sandy barriers was the final episode of sequential barrier formation results from sea level variations during the Quaternary. These variations culminated in the generation of the current landscape of coastal lagoons that characterizes the study area (Villwock \& Tomazelli 1995; Tomazelli et al. 2000).

Based on the differences of the ichthyofauna between rivers and lagoons of this region Malabarba \& Isaia (1992) recognized two discrete components in fish fauna of in the Rio Tramandaí drainage: the lowland fish fauna present in the lagoons and the riverine fish fauna in the valleys. For instance, 16 species found in the rivers have never been captured in the lagoons (Malabarba et al. 2013). Thus, these species are isolated within each river basin despite being part of a common drainage.

It has been suggested that the current patterns of distribution of this fish fauna in CDSEB rivers reflect past or present freshwater connections among these drainages (Weitzman et al. 1988; Lundberg et al. 1998). To test this hypothesis, we studied Cyanocharax itaimbe Malabarba \& Weitzman 2003 (Fig. 2), which is endemic to the Rio Tramandaí, Rio Mampituba and Rio Araranguá drainages. Cyanocharax itaimbe lives in strict riverine environments with clear, cold waters over rocky substrates, and is absent

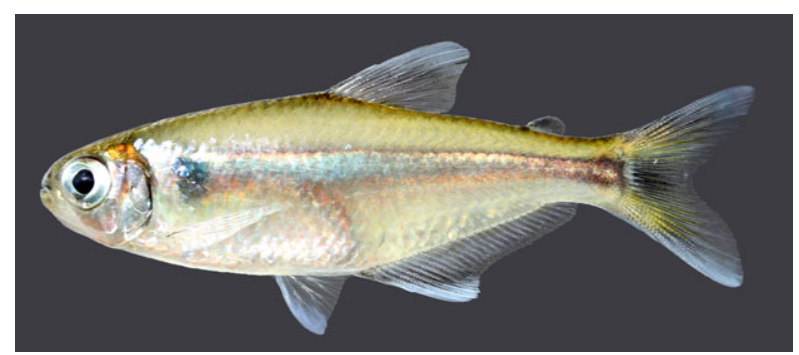

Fig. 2 Cyanocharax itaimbe, male, $52.1 \mathrm{~mm}$ SL (UFRGS 16499) collected in a tributary of the rio Três Forquilhas (FOR), Itati, Rio Grande do Sul state, Brazil. from coastal lagoons (Malabarba \& Weitzman 2003). If recent lowland freshwater connections were used by this species, the phylogeographic structure among drainages should be low. On the other hand, if $C$. itaimbe was always limited to riverine environments due to its ecological specialization, a strong phylogeographic structure is expected.

Although the isolated populations of C. itaimbe are morphologically similar, Malabarba \& Weitzman (2003) described significant differences in mean and median values of branched anal-fin ray counts among them, suggesting some population structure among drainages. These authors recognized two or three groups based on the mean and median of branched anal-fin rays. In the two-group classification, the population from Rio Araranguá, with a low number of branched anal-fin rays (median $=23$, mean $=22.9)$, is distinguished from the other populations (Rio Mampituba; Rio Três Forquilhas; Rio Maquiné; median $=24 ; 25 ; 25$ and mean $=23.9 ; 24.6 ; 24.7$ respectively). In the three-group classification, the population from Rio Mampituba is further distinguished from the others (Rio Três Forquilhas and Rio Maquiné) also by different count in branched anal-fin rays.

Based on the above cited historical landscape features and the morphological evidence, we hypothesize that, if the lagoons are acting as barriers to the recent dispersion between populations of this specialized riverine fish, we predict that this species will show significant genetic structure not only among isolated drainages (Rio Tramandaí, Rio Araranguá and Rio Mampituba), but also between the rivers within the Rio Tramandaí basin (Rio Maquiné and Rio Três Forquilhas). Otherwise, if this characid is able to use the lagoons for dispersion between the populations in these two rivers in the Tramandaí drainage, a lack of structure between these two populations would be predicted. Given that the overall biogeographic pattern exhibited by C. itaimbe is shared with several species, the results provide initial alternative evidence for the effect of freshwater lagoons on riverine dispersion along the southern Atlantic coast.

\section{Materials and methods}

Tissue samples from 55 specimens of Cyanocharax itaimbe were collected throughout its distribution and maintained in $96 \%$ ethanol in the fish collection at the Department of Zoology, Universidade Federal of Rio Grande do Sul (UFRGS). Samples include individuals from all four rivers systems in the range of this species (Rio Araranguá - ARA; Rio Mampituba - MAM; Rio Três Forquilhas - FOR; and Rio Maquiné - MAQ). Tissue samples from closely related species from the UFRGS fish collection were used as outgroups: one individual each of Cyanocharax alburnus (Hensel, 1870), C. alegretensis Malabarba \& Weitzman, 2003; C. dicropotamicus Malabarba \& Weitzman 2003; 
C. uruguayensis (Messner, 1962), Diapoma speculiferum Cope, 1894 and D. terofali (Géry, 1964) (Fig. 1, Table 1). COI sequences for C. alegretensis, C. uruguayensis and D. terofali were obtained from GenBank (FJ749047.1, FJ749049.1 and FJ749052.1; Javonillo et al. 2010).

DNA extraction from tissues followed a modified salt precipitation protocol (Medrano et al. 1990). For each sample we used PCR to amplify two mitochondrial genes: cytochrome oxidase subunit I (COI) and NADH dehydrogenase 2 (ND2); and three nuclear genes: $\mathrm{SH} 3$ and PX domaincontaining 3-like protein (SH3PX3), S7 ribosomal protein intron 2 (S72) (Cooke \& Beheregaray 2007) and myosin heavy chain 6 (Myb6) (Li et al. 2007). PCRs were carried out in $20 \mu \mathrm{L}$ reactions containing 10-50 ng DNA, $0.2 \mu \mathrm{M}$ of each primer, $0.2 \mathrm{mM}$ of each dNTP, $1 \times$ Buffer, $1.5 \mu \mathrm{M}$ $\mathrm{MgCl}_{2}$ and $1 \mathrm{U}$ Platinum Taq DNA polymerase (Invitrogen, São Paulo, SP, Brazil). PCR conditions and primers are presented in Appendix S1 Table S1. PCR products were checked by electrophoresis in agarose gel, purified using EXOSAP (Exonuclease I and Shrimp Alkaline Phosphatase GE Healthcare ${ }^{\circledR}$, Piscataway, NJ, USA) and sequenced in both directions by Macrogen Inc, Seoul, South Korea.

The mitochondrial coding genes COI and ND2 were concatenated for both phylogeographic and phylogenetic analyses whereas the nuclear genes were analysed separately or by using species-tree methods without concatenation (see below). Forward and reverse chromatogram reads were assembled and visualized using Geneious 5.6.7 - trial version (Drummond et al. 2012). The consensus sequences were automatically aligned using the software CLUSTALW (Thompson et al. 1994) with default parameters and implemented in BIOEDIT 7.1.3.0 (Hall 1999). We used the software package Phase version 2.1 (Stephens et al. 2001; Stephens \& Scheet 2005) to estimate haplotypes for the nuclear gene SH3PX3. Basic statistics, such as nucleotide $(\pi)$ and haplotype diversity (hd) as well as neutrality tests were calculated in the software DNASP v. 5 (Librado \& Rozas 2009).

We also constructed haplotype networks with the median-joining method (MJN) (Bandelt et al. 1999) using the program network 4.1.0.8 (www.fluxus-engineering.com). Calculation of F-statistics $\left(\Phi_{\mathrm{ST}}\right)$ and Analysis of Molecular Variance (AMOVA) were carried out in the program ARLEQUIN 3.5 (Excoffier et al. 2005). For these analyses, individuals sampled in the same river drainage were merged into a single population to quantify the amount of genetic structure amongst them. To test if MAQ and FOR may represent isolated populations, even though the coastal lagoons connect them, we kept them as two distinct populations. Thus, the analysis considered one group with four populations.

Phylogenetic relationships among populations of $C$. itaimbe and between $C$. itaimbe and outgroups were inferred by Bayesian inference (BI) and Maximum Parsimony (MP). Separate MP analyses for each partition (mitochondrial and nuclear) were conducted with TNT (Goloboff et al. 2008) using a traditional search with 200 replicates and tree bisection reconnection (TBR) algorithm branch swapping and 20 random taxon addition replicates. All characters were unordered with character transformations equally weighted. Clade robustness was assessed using 1000 bootstrap pseudoreplicates with the same search as above. BI

Table 1 Species, populations, voucher specimens and geographical coordinates for the tissues samples used in this study. All samples belong to UFRGS fish collection (Universidade Federal do Rio Grande do Sul)

\begin{tabular}{|c|c|c|c|c|}
\hline Species & Population (Drainage) & Voucher & Lat. (S) & Long. (W) \\
\hline \multirow[t]{12}{*}{ Cyanocharax itaimbe } & Maquiné/Tramandaí & UFRGS 12084/TEC1231A，C， E， F， H & $29^{\circ} 39^{\prime} 07^{\prime \prime}$ & $50^{\circ} 12^{\prime} 34^{\prime \prime}$ \\
\hline & Maquiné/Tramandaí & UFRGS 12634/TEC1369A， B， E， F， G，H & $29^{\circ} 35^{\prime} 02^{\prime \prime}$ & $50^{\circ} 16^{\prime} 51^{\prime \prime}$ \\
\hline & Três Forquilhas/Tramandaí & UFRGS 12585/TEC1261A， B, E， F, H & $29^{\circ} 29^{\prime} 09^{\prime \prime}$ & $50^{\circ} 07^{\prime} 15^{\prime \prime}$ \\
\hline & Três Forquilhas/Tramandaí & UFRGS 12587/TEC1263A，C， E， F， G，H & $29^{\circ} 29^{\prime} 01^{\prime \prime}$ & $50^{\circ} 05^{\prime} 59^{\prime \prime}$ \\
\hline & Três Forquilhas/Tramandaí & UFRGS 16517/TEC2845A, B, C & $29^{\circ} 25^{\prime} 36^{\prime \prime}$ & $50^{\circ} 10^{\prime} 44^{\prime \prime}$ \\
\hline & Mampituba & UFRGS 12534/TEC1236E & $29^{\circ} 14^{\prime} 49^{\prime \prime}$ & $50^{\circ} 4^{\prime} 12^{\prime \prime}$ \\
\hline & Mampituba & UFRGS 12600/TEC1300A，B，C，D，E & $29^{\circ} 23^{\prime} 53^{\prime \prime}$ & $49^{\circ} 55^{\prime} 04^{\prime \prime}$ \\
\hline & Mampituba & UFRGS 12620/TEC1355A，C，D，E，F， G & $29^{\circ} 11^{\prime} 41^{\prime \prime}$ & $49^{\circ} 57^{\prime} 55^{\prime \prime}$ \\
\hline & Mampituba & UFRGS 12635/TEC1370B， D， E， F， G & $29^{\circ} 08^{\prime} 29^{\prime \prime}$ & $49^{\circ} 53^{\prime} 35^{\prime \prime}$ \\
\hline & Araranguá & UFRGS 12625/TEC1360A, E, H & $28^{\circ} 47^{\prime} 53^{\prime \prime}$ & $49^{\circ} 42^{\prime} 57^{\prime \prime}$ \\
\hline & Araranguá & UFRGS 12627/TEC1362A, B, C, D, E, F, H & $28^{\circ} 30^{\prime} 39^{\prime \prime}$ & $49^{\circ} 28^{\prime} 44^{\prime \prime}$ \\
\hline & Araranguá & UFRGS 16567/TEC2899A，B，C & $28^{\circ} 36^{\prime} 35^{\prime \prime}$ & $49^{\circ} 33^{\prime} 16.2^{\prime \prime}$ \\
\hline Cyanocharax dicropotamicus & Laguna dos Patos & UFRGS 12727/TEC1465A & $28^{\circ} 56^{\prime} 07^{\prime \prime}$ & $51^{\circ} 26^{\prime} 35^{\prime \prime}$ \\
\hline Cyanocharax alburnus & Lagoa dos Quadros/Tramandaí & UFRGS 12087/TEC1234A & $29^{\circ} 40^{\prime} 35^{\prime \prime}$ & $50^{\circ} 08^{\prime} 29^{\prime \prime}$ \\
\hline Cyanocharax uruguayensis & Uruguay & UFRGS 10000/TEC46 & $31^{\circ} 6^{\prime} 58^{\prime \prime}$ & $55^{\circ} 24^{\prime} 56^{\prime \prime}$ \\
\hline Diapoma speculiferum & Laguna dos Patos & UFRGS 12388/TEC692 & $30^{\circ} 8^{\prime} 53.35^{\prime \prime}$ & $52^{\circ} 2^{\prime} 48.58^{\prime \prime}$ \\
\hline Diapoma terofali & Uruguay & UFRGS 10007/TEC15 & $30^{\circ} 12^{\prime} 42.80^{\prime \prime}$ & $55^{\circ} 3^{\prime} 17.50^{\prime \prime}$ \\
\hline
\end{tabular}


using two gene trees (mt- and nDNA) and species tree analysis were implemented in BEAST 1.7.5 (Drummond \& Rambaut 2007). This program was also used to estimate dynamics of population size fluctuation over time for C. itaimbe, based on the mtDNA dataset under the Extended Bayesian Skyline Plot (EBSP) method (Heled \& Drummond 2008). The mtDNA data set was analysed assuming an evolutionary rate of $0.01 / \mathrm{site} / \mathrm{Myr}$ (Bermingham et al. 1997; Reeves \& Bermingham 2006; Ornelas-García et al. 2008) and a strict clock model, which is a generally welljustified analysis within a species or among a few closely related species (Li \& Drummond 2012). The evolutionary rate for $\mathrm{SH}_{3} \mathrm{PX} 3$ was calibrated based on the mtDNA rate. We used the Bayesian Information Criterion in PartitionFinder (Lanfear et al. 2012) to assume the HKY+I substitution model for COI, TN93+I for ND2 and HKY for SH3PX3. For the gene tree estimation, we used 10 million MCMC steps for both mtDNA and SH3PX3, while 100 million MCMC steps were performed for species tree estimation. For the EBSP method, the search lasted 50 million MCMC steps. In all cases, samples were collected every 1000 steps and the efficiency of the chain was assessed in Tracer 1.5 with 10\% burn-in. We used Bayes Factors (Kass \& Raftery 1995) for the species tree analyses to evaluate the model evidence for six different schemes for defining terminals: (i) considering collection sites as terminals (12 terminals); (ii) considering river systems as terminals (four terminals); (iii) considering $\mathrm{MAQ}+\mathrm{FOR}+\mathrm{MAM}$ as one terminal and ARA as a different terminal (two terminals); (iv) considering FOR+MAM as one terminal, MAQ as another terminal and ARA as a third terminal (based in three mtDNA clades (3 terminals); (v) considering the system of three drainages as terminals (three terminals, MAQ+FOR, MAM, ARA); and (vi) considering all C. itaimbe populations as a single terminal (one terminal).

\section{Results}

A total alignment of 1490 base pairs (bp) was obtained for the mitochondrial genes COI (563 bp) and ND2 (927 bp). The nucleotide and haplotype diversity were 0.014 and 0.97 , respectively. A total of 86 polymorphic sites defining 33 different haplotypes for C. itaimbe were found. Neutrality tests failed to reject the null hypothesis of no evidence of natural selection and/or constant population size (Tajima's D $-0.045, P>0.10$; Fu's FS $-0.30, P=0.23$ ). In agreement with the results from the neutrality tests, the EBSP approach for mtDNA suggests that $C$. itaimbe maintained a highly effective population size $(\mathrm{Ne})$ over time, suggesting absence of population expansion (Fig. S1 in Appendix S2).

We obtained an alignment of $371 \mathrm{bp}$ and $779 \mathrm{bp}$ for the S72 gene and Myb6 gene, respectively, but both of them were not variable in the studied species and, therefore, not used in the analyses. For the SH3PX3 gene, we obtained an alignment of $700 \mathrm{bp}$ containing seven variable sites which defined nine different haplotypes in C. itaimbe. Nucleotide and haplotype diversity were 0.002 and 0.68 , respectively, and as with mtDNA the neutrality tests did not indicate violations of the null model (Tajima's D $-0.097 ; P>0.10$; Fu's FS $-0.29 ; P=0.30)$. New sequences generated in this study were submitted to GenBank (KP399679 to KP399736; KP406648 to KP406708; KP636960 to KP637020).

Mitochondrial data showed a strong genetic structure (Fig. 3a), with three well defined groups. The first group consists of haplotypes sampled in populations collected in MAM and FOR. The second group is composed exclusively of haplotypes sampled in MAQ. Finally, the last group consists of haplotypes only observed in ARA. On the other hand, the haplotype network for gene SH3PX3 (Fig. 3b) showed a central haplotype shared by all populations. Among haplotypes with more restricted geographic distributions, there are interestingly some haplotypes exclusive in ARA, whereas others are shared only between MAM and FOR. MAQ population had only the central haplotype and showed a remarkably low diversity. Overall, both networks appear to be congruent with respect to each other. In agreement with the haplotype networks, the AMOVA (Table 2) shows high isolation among river systems for the mtDNA data $\left(\Phi_{\mathrm{ST}}=0.85\right)$, while the genetic structure for $\mathrm{nDNA}$ was much more modest $\left(\Phi_{\mathrm{ST}}=0.32\right)$.

Both phylogenetic methods (BI and MP) produced gene trees with similar topologies, and, therefore, we only present results for BI. The Mitochondrial gene tree was congruent with haplotype network and clearly distinguishes three clades within $C$. itaimbe with high posterior probability (PP) values (Fig. S2 in Appendix S2). The first clade is represented by ARA, which is sister to a clade formed by the two other clades, with separate haplotypes from MAQ and $\mathrm{MAM}+\mathrm{FOR}$. As expected due to low sequence divergence, the gene tree for SH3PX3 did not show strong support for any specific clade within $C$. itaimbe and the species was not recovered as a monophyletic group (Fig. S3 in Appendix S2).

The species tree was the one with strongest support (log10 Bayes Factors $>1$ against one tree and $>4$ against others) based on the three mtDNA clades (Fig. 4, Table S2 in Appendix S1). This tree shows that MAQ and FOR + MAM are sister clades ( $P P=0.99)$, and that ARA is sister to this clade ( $\mathrm{PP}=0.99)$. According to the best supported species tree, ARA diverged from the remaining populations in the Pleistocene, around 1.6 Ma (95\% Highest Posterior Density (HPD) between 0.7-2.9 Ma). This is very similar to the estimated divergence between two other species, C. alburnus and C. dicropotamicus, which comprise the sister clade of $C$. itaimbe and whose divergence is esti- 
Fig. 3 Median-joining networks among haplotypes of Cyanocharax itaimbe samples: (A) inferred by the concatenated $\mathrm{mtDNA}$ dataset $(C O I+N D 2)$ and $(\mathrm{B})$ inferred by nDNA (SH3PX3). Each circle represents a unique haplotype with circle sizes being proportional to their frequencies. Each colour represents a population as in Fig. 1. Crossed markers indicate the number of mutations between haplotypes.
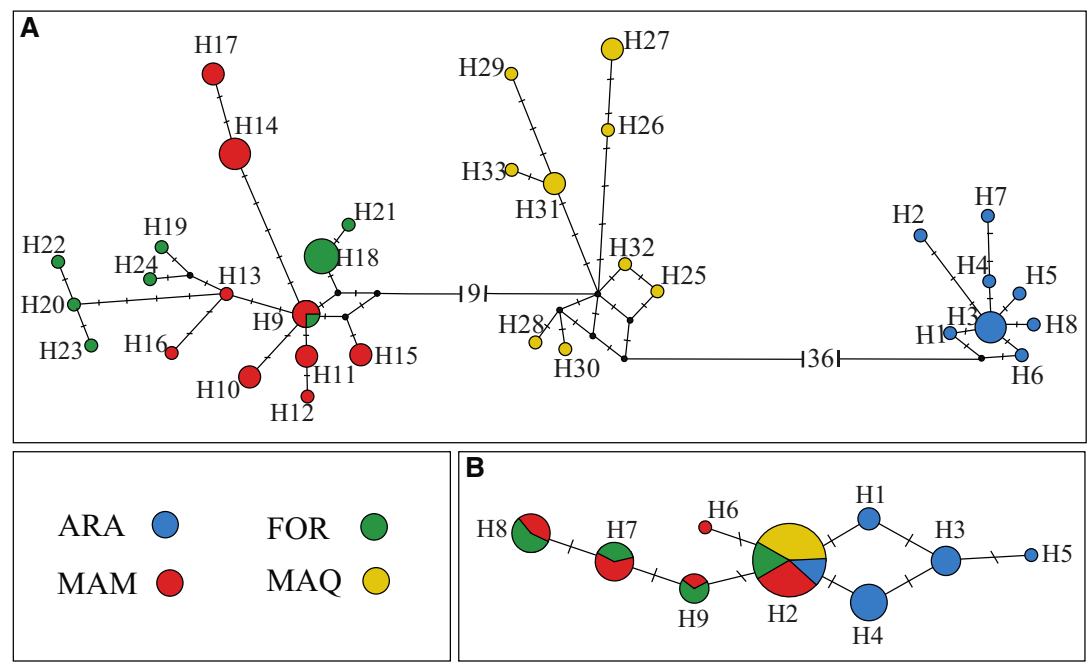

Table 2 Results from the analysis of molecular variance (AMOVA) among and within Cyanocharax itaimbe populations for the mtDNA and nDNA data

\begin{tabular}{|c|c|c|c|c|c|c|}
\hline \multirow[b]{2}{*}{ Source of variation } & \multicolumn{3}{|c|}{ mtDNA } & \multicolumn{3}{|c|}{ nDNA } \\
\hline & d.f. & $\%$ variation & $P$-value & d.f. & $\%$ variation & $P$-value \\
\hline Among populations & 3 & 85.02 & $<0.001$ & 3 & 31.58 & $<0.001$ \\
\hline Within populations & 51 & 14.98 & $<0.001$ & 106 & 68.42 & $<0.001$ \\
\hline Fixation Index $\Phi$ & \multicolumn{2}{|c|}{0.85017} & $<0.001$ & \multicolumn{2}{|c|}{0.31581} & $<0.001$ \\
\hline
\end{tabular}

mated to be around $1.8 \mathrm{Ma}$ (95\% HPD $0.75-3.00 \mathrm{Ma}$ ). Divergence between the remaining clades within C. itaimbe is estimated roughly $0.45 \mathrm{Ma}$ (95\% HPD $0.20-0.90 \mathrm{Ma})$. The estimated evolutionary rate for the $S H 3 P X 3$ gene relative to the mtDNA rate is as $0.000545 /$ site/Myr $(95 \%$ HPD 0.000183-0.000936/site/Myr).

\section{Discussion}

Our results estimate that $C$. itaimbe from MAQ diverged from the FOR+MAM clade about $450 \mathrm{ka}$ in the Pleistocene, an event synchronous with the initial establishment of the modern coastal plain in southern Brazil. This result does not corroborate the three-group hypothesis of Malabarba \& Weitzman (2003) based on morphology. The geomorphological history of this area is well-known and the age of the depositional environments indicates that it has evolved from sediment deposition through a minimum of four successive trans-regressive cycles that occurred during the last $500 \mathrm{ka}$ (Villwock 1984; Villwock \& Tomazelli 1995; Buchmann et al. 1998). This demonstrates that, besides the potential connections between MAQ and FOR drainages during several marine regressions and the current connection by the freshwater lagoons, the populations of these two rivers remained isolated long-term.
According to Albert \& Reis (2011), Neotropical rivers and floodplains often represent dispersal corridors for freshwater fishes. In the case of basins along the coast of Brazil, sea level retreats during glaciation periods would have created temporary connections among presently isolated basins, allowing fishes to disperse between them (Weitzman et al. 1988; Lundberg et al. 1998). However, such connections may not represent dispersal corridors for ichthyofauna as a whole (Albert \& Reis 2011). In the case of species adapted to upstream environments the lowland environments may represent a barrier to gene flow among adjacent drainages. This seems to be the case for $C$. itaimbe. The absence of shared haplotypes between FOR and MAQ, with FOR being the sister clade of MAM, instead of MAQ, indicate that, although FOR and MAQ are currently connected through freshwater lagoons, the latter water bodies act as filters to the dispersion of this species. Past or present lowland river connections cannot be considered the unique feature determining current distribution of freshwater fish lineages along the CDSEB. Instead, the results obtained from $C$. itaimbe confirm that lagoons or possible lowland connections may act as barriers to dispersion between populations of specialized riverine fish. In a similar way, large rivers can act as geographic barriers or natural 


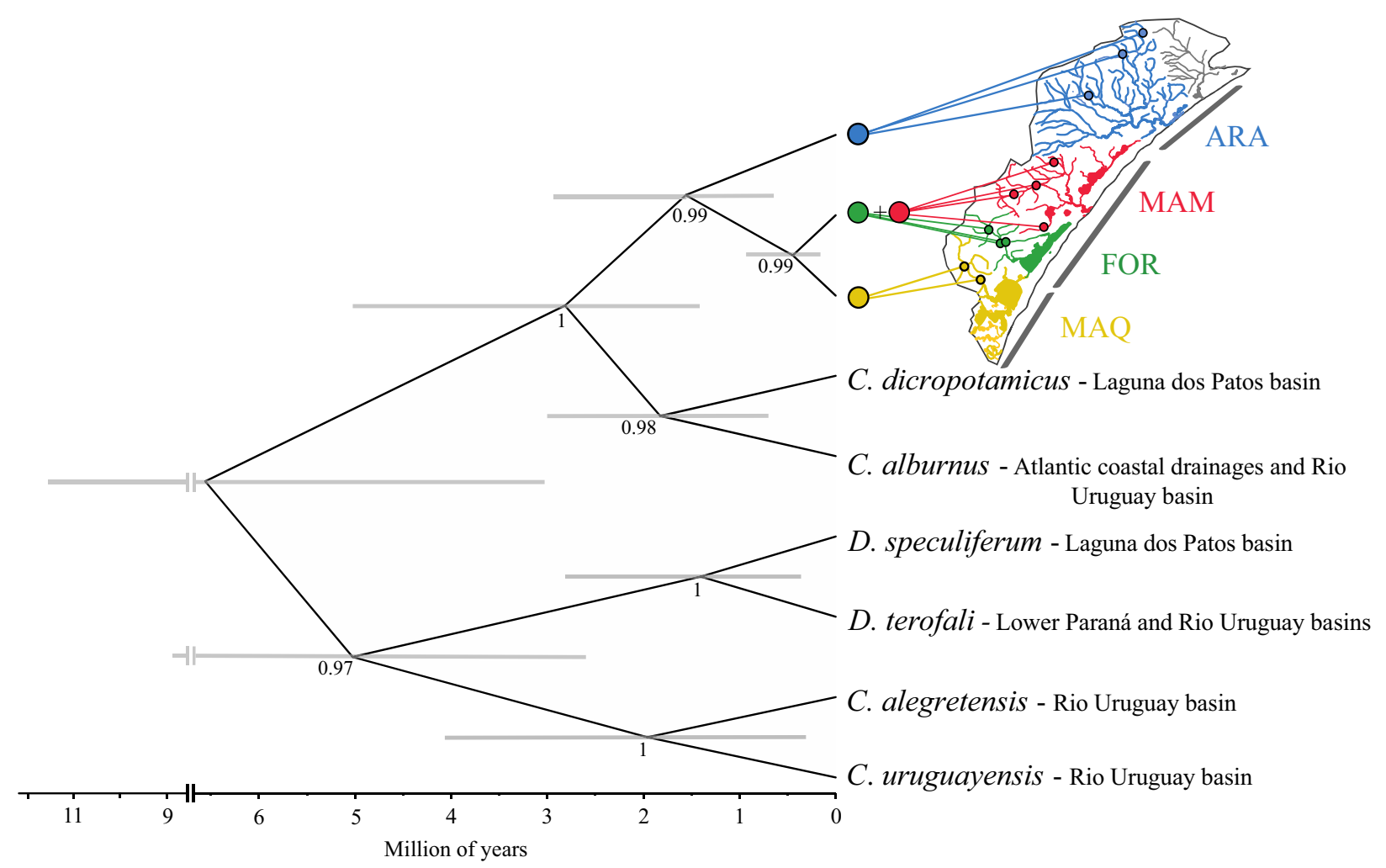

Fig. 4 Species tree with strongest support according to Bayes Factor value. Black numbers on the nodes represent posterior probabilities higher than 0.5 and the grey represents error bars obtained from molecular clock estimate. The colours indicate the sampled population as in Fig. 1.

ecological barriers for fish dispersal processes due to differences in water chemistry or obstacles like waterfalls and rapids (Junk \& Soares 2001; Ingenito \& Buckup 2007; Torrente-Vilara et al. 2011). For example, in the Amazonian region a southern-northern shift in the distribution of fish species and/or genetic diversity can be attributed to the main channel of the Amazon River acting as a physical barrier to dispersal (Hubert \& Renno 2006).

Interestingly, in the Rio Tramandaí drainage there is a notable division in the composition of the freshwater fish fauna, with different species found in the major rivers within the Serra Geral Formation and in the lagoons of the coastal plain (Malabarba \& Isaia 1992; Malabarba et al. 2013). Several species (e.g. C. itaimbe, Deuterodon stigmaturus Gomes (1947), Epactionotus bilineatus Reis \& Schaefer 1998; Hollandicbthys taramandaby Bertaco \& Malabarba 2013, Fenynsia unitaenia Ghedotti \& Weitzman 1995, Mimagoniates rheocharis Menezes \& Weitzman 1990, Odontostoechus lethostigmus Gomes 1947, Pareiorbaphis hypselurus (Pereira \& Reis 2002), P. nudulus (Reis \& Pereira 1999), Rineloricaria aequalicuspis Reis \& Cardoso 2001, and R. maquinensis Reis \& Cardoso 2001) are restricted to the upland portion of these drainages. These species have smaller ranges than do species occurring in the lowland coastal plain portions of these rivers (e.g. C. alburnus (Hensel, 1870), Jenynsia multidentata (Jenyns, 1842), Loricariichthys anus (Valenciennes, 1836) and Rineloricaria quadrensis Reis, 1983). Selective dispersion through coastal rivers or palaeochannels connected with such water bodies along the extended coastal plain during glacial periods acts as dispersal corridors for some species and also as effective freshwater barriers for others. Additional phylogeographic studies comparing patterns found in species from the coastal lagoons and rivers in the Serra Geral will be useful to test this hypothesis. The shared haplotypes between FOR and MAM, despite the present occurrence of these populations in different drainages, may indicate an ancestral relationship between these populations or recent gene flow due to headwater capture, a process still active in the rivers of the coastal region (Ribeiro 2006).

ARA diverged from the remaining C. itaimbe populations in the Pleistocene, about 1.6 Ma. Thus, our results corroborate the two-group hypothesis of Malabarba \& Weitzman (2003) based on morphology. During the Pleistocene, the Rio Araranguá basin was probably the first of these basins to lose its connection with the neighbouring drainages, with consequent isolation of this population. The low 
evolutionary rate of the $S H 3 P X 3$ gene, its larger population size compared to mtDNA genes, and the relatively recent divergence time estimated between these populations make the lack of reciprocal monophyly between ARA and the remaining $C$. itaimbe populations unsurprising.

The only morphological difference found between the populations was the anal-fin rays count. The population of ARA significantly differ from the other three populations (MAM, FOR, MAQ), while MAM show a smaller deviation (but still significant) from FOR and MAQ. This morphological character agrees with our molecular data in relation to ARA differing from the other populations. However, the difference between MAM from FOR and MAQ was less significant and does not reflect diverging clades in our mtDNA analysis.

In conclusion, our data support the interpretation that genetic structure found in C. itaimbe is explained by ecological factors that impede gene flow between river systems, notwithstanding their current connection by freshwater coastal lagoons, as is the case of MAQ and FOR populations. This also indicates that past lowland river connections between CDSEB due to sea level retreats during glaciation periods may have been selective and may not have represented dispersal corridors for the whole ichthyofauna. Other factors that could have facilitated headwater capture in the upper portion of these rivers may have also played a role, as seen in the case of extensive haplotype sharing between the currently isolated FOR and MAM populations.

\section{Acknowledgements}

This work was supported by the Conselho Nacional de Desenvolvimento Científico e Tecnológico $(\mathrm{CNPq})$. We thank Juliana M. Wingert, Aline Fregonezi and Renata Fagundes for technical help; Karina V. V. de Oliveira for assistance in the molecular biology laboratory at Departamento de Zoologia, UFRGS; Augusto Ferrari for help with the map and Jordan Bemmels and Richard P. Vari for English review. LRM's research is supported by $\mathrm{CNPq}$ (300705/2010-7; 477318/2012-6).

\section{References}

Abell, R., Thieme, M. L., Revenga, C., Bryer, M., Kottelat, M., Bogutskaya, N., Coad, B., Mandrak, N., Balderas, S. C., Bussing, W., Stiassny, M. L. J., Skelton, P., Allen, G. R., Unmack, P., Naseka, A., Ng, R., Sindorf, N., Robertson, J., Armijo, E., Higgins, J. V., Heibel, T. J., Wikramanayake, E., Olson, D., López, H. L., Reis, R. E., Lundberg, J. G., Pérez, M. H. S., \& Petry, P. (2008). Freshwater ecoregions of the world: a new map of biogeographic units for freshwater biodiversity conservation. BioScience, 58, 403-414.

Albert, J. S. \& Reis, R. E. (2011). Historical Biogeography of Neotropical Freshwater Fishes. Berkeley, CA: University of California Press, 388 pp.
Avise, J. C. (2000). Phylogeography: The History and Formation of Species. Cambridge, MA: Harvard University Press.

Avise, J. C. (2009). Phylogeography: retrospect and prospect. Fournal of Biogeography, 36, 3-15.

Bandelt, H. J., Forster, P. \& Röhl, A. (1999). Median-joining networks for inferring intraspecific phylogenies. Molecular Biology and Evolution, 16, 37-48.

Bermingham, E. \& Avise, J. C. (1986). Molecular zoogeography of freshwater fishes in the southeastern United States. Genetics, 113, 939-965.

Bermingham, E., McCafferty, S. S. \& Martin, A. P. (1997). Fish biogeography and molecular clocks: perspectives from the Panamanian Isthmus. In T. D. Kocher \& C. A. Stepien (Eds) Molecular Systematics of Fishes (pp. 113-128). San Diego: Academic Press.

Bernatchez, L. \& Wilson, C. C. (1998). Comparative phylogeography of Nearctic and Palearctic freshwater fishes. Molecular Ecology, 7, 431-452.

Bizerril, C. R. S. F. (1994). Análise taxonômica e biogeográfica da ictiofauna de água doce do leste brasileiro. Acta Biologica Leopoldensia, 16, 51-80.

Buchmann, F. S. C., Barbosa, V. P. \& Villwock, J. A. (1998). Sedimentologia e paleoecologia durante o máximo transgressivo holocênico na Lagoa Mirim, RS, Brasil. Acta Geologica Leopoldensia, 21, 21-26.

Buckup, P. A. (2011). The eastern Brazilian Shield. In J. S. Albert \& R. E. Reis (Eds) Historical Biogeography of Neotropical Freshwater Fishes (pp. 203-210). Berkeley, CA: University of California Press.

Carnaval, A. C. \& Moritz, C. (2008). Historical climate modelling predicts patterns of current biodiversity in the Brazilian Atlantic forest. Fournal of Biogeography, 35, 1187-1201.

Carnaval, A. C., Hickerson, M. J. \& Haddad, C. F. B. (2009). Stability predicts genetic diversity in the Brazilian Atlantic forest hotspot. Science, 323, 785-789.

Cooke, G. M. \& Beheregaray, L. B. (2007). Extremely high variability in the S72 intron of the Amazonian cardinal tetra (Paracheirodon axelrodi). Fournal of Fish Biology, 71, 132-140.

Drummond, A. J. \& Rambaut, A. (2007). BEAST: Bayesian evolutionary analysis by sampling trees. BMC Evolutionary Biology, 7, 214-221.

Drummond, A. J., Ashton, B., Buxton, S., Cheung, M., Cooper, A., Duran, C., Heled, J., Kearse, M., Markowitz, S., Moir, R., StonesHavas, S., Sturrock, S., Swidan, F., Thierer, T. \& Wilson, A. (2012). Geneious v5.6, Available from http://www.geneious.com.

Excoffier, L., Laval, G. \& Schneider, S. (2005). Arlequin ver. 3.0: an integrated software package for population genetics data analysis. Evolutionary Bioinformatics Online, 1, 47-50.

Goloboff, P. A., Farris, J. S. \& Nixon, K. C. (2008). TNT, a free program for phylogenetic analyses. Cladistics, 24, 774-786.

Hall, T. A. (1999). BioEdit: a user-friendly biological sequence alignment editor and analysis program for Windows 95/98/NT. Nucleic Acids Symposium Series, 41, 95-98.

Heled, J. \& Drummond, A. J. (2008). Bayesian inference of population size history from multiple loci. BMC Evolutionary Biology, 8, 289-303.

Hubert, N. \& Renno, F. (2006). Historical biogeography of South American freshwater fishes. Fournal of Biogeography, 11, 1414-1436.

Ingenito, L. F. S. \& Buckup, P. A. (2007). The Serra da Mantiqueira, Southeastern Brazil, as a Biogeographical Barrier for Fishes. Fournal of Biogeography, 34, 1173-1182. 
Javonillo, R., Malabarba, L. R., Weitzman, S. H. \& Burns, J. R. (2010). Relationships among major lineages of characid fishes (Teleostei: Ostariophysi: Characiformes), based on molecular sequence data. Molecular Phylogenetics and Evolution, 54, 498-511.

Junk, W. J. \& Soares, M. G. M. (2001). Freshwater fish habitats in Amazonia: state of knowledge, management, and protection. Aquatic Ecosystem Health \& Management, 4, 437-451.

Kass, R. E. \& Raftery, A. E. (1995). Bayes Factors. Fournal of the American Statistical Association, 90, 773-795.

Lanfear, R., Calcott, B., Ho, S. Y. W. \& Guindon, S. (2012). PartitionFinder: combined selection of partitioning schemes and substitution models for phylogenetic analyses. Molecular Biology and Evolution, 29, 1695-1701.

Li, W. L. S. \& Drummond, A. J. (2012). Model averaging and Bayes factor calculation of relaxed molecular clocks in Bayesian phylogenetics. Molecular Biology and Evolution, 29, 751-761.

Li, C., Ortí, G., Zhang, G. \& Lu, G. (2007). A practical approach to phylogenomics: the phylogeny of ray-finned fish (Actinopterygii) as a case study. BMC Evolutionary Biology, 7, 44.

Librado, P. \& Rozas, J. (2009). DnaSP v5: a software for comprehensive analysis of DNA polymorphism data. Bioinformatics, 25, $1451-1452$.

Lundberg, J. G., Marshall, L. G., Guerrero, J., Horton, B., Malabarba, M. C. S. L. \& Wesselingh, F. (1998). The stage for Neotropical fish diversification: a history of tropical South American rivers. In L. R. Malabarba, R. E. Reis, R. P. Vari, Z. M. S. Lucena \& C. A. S. Lucena (Eds) Phylogeny and Classification of Neotropical Fishes (pp. 13-48). Porto Alegre: Edipucrs.

Malabarba, L. R. \& Isaia, E. A. (1992). The fresh water fish fauna of the rio Tramandaí drainage, Rio Grande do Sul, Brazil, with a discussion of its historical origin. Comunicações do Museu de Ciências e Tecnologia, PUCRS, Série Zoologia, 5, 197223.

Malabarba, L. R. \& Weitzman, S. H. (2003). Description of a new genus with six new species from Southern Brazil, Uruguay and Argentina, with a discussion of a putative Characid clade (Teleostei: Characiformes: Characidae). Comunicações do Museu de Ciências PUCRS, Série Zoologia, 16, 67-151.

Malabarba, L. R., Neto, P. C., Bertaco, V. A., Carvalho, T. P., dos Santos, J. F. \& Artioli, L. G. S. (2013). Guia de identificação dos peixes da bacia do rio Tramandaí. Ed. Via Sapiens, Porto Alegre, RS, 140 p.

Medrano, J. F., Aasen, E. \& Sharrow, L. (1990). DNA extraction from nucleated red blood cells. BioTechniques, 8, 43.

Myers, N., Mittermeier, R. A., Mittermeier, C. G., Fonseca, G. A. B. \& Kent, J. (2000). Biodiversity hotspots for conservation priorities. Nature (London), 403, 853-858.

Ornelas-García, C. P., Domínguez-Domínguez, O. \& Doadrio, I. (2008). Evolutionary history of the fish genus Astyanax Baird \& Girard (1854) (Actinopterygii, Characidae) in Mesoamerica reveals multiple morphological homoplasies. BMC Evolutionary Biology, 8, 340-357.

Reeves, R. G. U. Y. \& Bermingham, E. (2006). Colonization, population expansion, and lineage turnover: phylogeography of Mesoamerican characiform fish. Biological fournal of the Linnean Society, 88, 235-255.

Reis, R. E. \& Schaefer, S. A. (1998). New cascudinhos from southern Brazil: systematics, endemism, and relationships (Silurifor- mes, Loricariidae, Hypoptopomatinae). American Museum Novitates, 3254, 1-25.

Ribeiro, A. C. (2006). Tectonic history and the biogeography of the freshwater fishes from the coastal drainages of eastern Brazil : an example of faunal evolution associated with a divergent continental margin. Neotropical Ichthyology, 4, 225-246.

Rundle, H. D., Nagel, L., Boughman, J. W. \& Schluter, D. (2000). Natural selection and parallel speciation in sympatric sticklebacks. Science, 287, 306-308.

Schwarzbold, A. \& Schäfer, A. (1984). Gênese e Morfologia das Lagoas Costeiras do Rio Grande do Sul - Brasil. Amazoniana, 9, 87-104.

Stephens, M. \& Scheet, P. (2005). Accounting for Decay of Linkage Disequilibrium in Haplotype Inference and Missing-Data Imputation. American Fournal of Human Genetics, 76, 449-462.

Stephens, M., Smith, N. \& Donnelly, P. (2001). A new statistical method for haplotype reconstruction from population data. American fournal of Human Genetics, 68, 978-989.

Thompson, J. D., Higgins, D. G. \& Gibson, T. J. (1994). CLUSTAL W: improving the sensitivity of progressive multiple sequence" alignment through sequence weighting, position specific gap penalties and weight matrix choice. Nucleic Acids Research, 22, 4673-4680.

Tomazelli, L. J., Dillenburg, S. R. \& Villwock, J. A. (2000). Late Quaternary geological history of Rio Grande do Sul coastal plain, southern Brazil. Revista Brasileira de Geociências, 30, 474-476.

Torrente-Vilara, G., Zuanon, J., Leprieur, F., Oberdorff, T. \& Tedesco, P. A. (2011). Effects of natural rapids and waterfalls on fish assemblage structure in the Madeira River (Amazon Basin). Ecology of Freshwater Fish, 20, 588-597.

Vari, R. P. (1988). The Curimatidae, a lowland Neotropical fish family (Pisces: Characiformes): distribution, endemism, and phylogenetic biogeography. In P. E. Vanzolini \& W. R. Heyer (Eds), Proceedings of a Workshop on Neotropical Distribution Patterns (pp. 343-377). Rio de Janeiro, Brazil: Academia Brasileira de Ciências.

Villwock, J. A. (1984). Geology of the coastal province of the Rio Grande do Sul, Southern Brazil. A synthesis. Pesquisas em Geociências, 16, 5-49.

Villwock, J. A. \& Tomazelli, L. J. (1995). Geologia costeira do Rio Grande do Sul. Notas Técnicas, 8, 1-45.

Waters, J. M., Rowe, D. L., Apte, S., King, T. M, Wallis, G. P., Anderson, L., Norris, R. J., Craw, D., Burridge, C. P. (2007). Geological dates and molecular rates: rapid divergence of rivers and their biotas. Systematic Biology, 56, 271-282.

Weitzman, S. H., Menezes, N. A. \& Weitzman, M. J. (1988). Phylogenetic biogeography of the Glandulocaudini (Teleostei: Characiformes, Characidae) with comments on the distribution of other freshwater fishes in eastern and southeastern Brazil. In P. E. Vanzolini \& W. R. Heyer (Eds), Proceedings of a Workshop on Neotropical Distribution Patterns (pp. 379-427). Rio de Janeiro, Brazil: Academia Brasileira de Ciências.

\section{Supporting Information}

Additional Supporting Information may be found in the online version of this article:

Appendix S1. Additional tables (S1 and S2).

Appendix S2. Additional figures (S1-S3). 